\title{
Pengembangan Media Pembelajaran Berbasis Mobile Application Pembuatan Kerah Jas Pria pada Matakuliah Tailoring Program Studi S1 Pendidikan Tata Busana Universitas Negeri Malang
}

\author{
Suryaningati, Idah Hadijah*, Nanda Desty Dwi, Sri Eko Puji Rahayu \\ Universitas Negeri Malang, Jl. Semarang No. 5 Malang, Jawa Timur, Indonesia \\ *Penulis korespondensi, Surel: idahrohman@um.ac.id
}

Paper received: 06-04-2021; revised: 18-04-2021; accepted: 21-04-2021

\begin{abstract}
Tailoring is one of the subjects for student in fashion department Universitas Negeri Malang. Student had difficulty when they sew men's collar jacket on sewing a men's jacket material. The main factor that makes the students feel difficult because there is no supporting media. To solve this problem, researcher developed the attractive learning media to make it easy to understand. Hence, the purpose of this study is to produce a new media based on mobile application that focused on how to sew a men's collar jacket. This media can used in the Android cell phone. This study used ADDIE development. The results of the validity test showed that the percentage of validity from material experts is 90.63 percent, the validity percentage of media experts is 95 percent, and the validity percentage of linguists is 92.11 percent. Meanwhile, on the trial of small group that test on 30 respondents, the percentage of eligibility 88,56 percent, so this learning media based on mobile application could be considered valid and helpful for learning activity. Recommendation for the next development is to add animation elements in the learning media that make more attractive and to increase students understanding. Hopefully, the next researcher can add another material for this learning media.
\end{abstract}

Keywords: media learning; mobile application; men’s collar jacket

\begin{abstract}
Abstrak
Mahasiswa S1 Pendidikan Tata busana dalam matakuliah praktik tailoring pembuatan kerah jas pada materi menjahit jas pria mengalami kesulitan. Faktor utama penyebab mahasiswa mengalami kesulitan tersebut karena belum adanya media pendukung sehingga perlu dikembangkan media pembelajaran yang lebih menarik agar dapat meningkatkan minat belajar mahasiswa. Tujuan penelitian pengembangan ini dilakukan untuk menghasilkan media berbasis mobile application tentang cara pembuatan kerah jas pria. Prosedur pengembangan ini menggunakan model pengembangan. Hasil uji validasi diperoleh hasil persentasi kevalidan ahli materi sebesar 90,63 persen, persentase kevalidan ahli media sebesar 95 persen, dan persentase kevalidan ahli bahasa sebesar 92,11 persen. Sedangkan pada uji coba kelompok kecil yang dilakukan pada mahasiswa S1 Pendidikan Tata Busana Universitas Negeri Malang berjumlah 30 responden, diperoleh hasil persentase kelayakan media sebesar 88,56 persen sehingga media pembelajaran berbasis mobile application pembuatan kerah jas pria dapat dinyatakan valid dan layak digunakan untuk proses belajar mengajar. Adapun saran pengembangan produk lebih lanjut sebaiknya menambahkan elemen animasi pada media pembelajaran agar lebih menarik dan dapat meningkatkan pemahaman mahasiswa serta menambahkan materi lain yang lebih luas.
\end{abstract}

Kata kunci: media pembelajaran; mobile application; kerah jas pria

\section{Pendahuluan}

Tailoring merupakan salah satu Matakuliah Keahlian Berkarya dalam Program Studi S1 Pendidikan Tata Busana, dimana matakuliah tersebut memiliki tingkat kesulitan yang tinggi 
sehingga penguasaan teknik yang tepat sangat dibutuhkan untuk menghasilkan jahitan yang berkualitas. Pembuatan jas pria merupakan salah satu materi praktik dalam matakuliah tailoring Program Studi S1 Pendidikan Tata Busana Universitas Negeri Malang, dimana dalam pembuatan kerah jas terdiri dari beberapa komponen kecil salah satunya yaitu kerah jas. Teknik yang benar serta kerapihan hasil jahitan pada pembuatan komponen-komponen busana tersebut sangat penting untuk meningkatkan nilai estetika dalam keseluruhan hasil jas pria. Kerah adalah salah satu komponen pada busana jas pria yang paling menonjol dan paling menarik perhatian, sehingga apabila hasil jahitan kerah tidak rapi maka akan dapat mengurangi nilai estetika dari busana itu sendiri.

Berdasarkan hasil penelitian Usman (2013:40) menemukan bahwa terdapat kesulitan yang dialami oleh mahasiswa dalam pembuatan kerah jas, melalui identifikasi tingkat kesulitan sewing pada pembuatan blazer/jas menunjukkan bahwa sebanyak $61,11 \%$ menyatakan cukup sulit. Sebanyak sembilan belas(19) item identifikasi tingkat kesulitan sewing pada pembuatan blazer/jas, item memasang kerah berada pada urutan tingkat kesulitan kedua setelah menjahit belahan belakang pada pembuatan blazer/jas, sedangkan item menjahit kerah berada pada urutan tingkat kesulitan keenam.

Setelah peneliti melakukan observasi awal terhadap mahasiswa S1 Pendidikan Tata Busana angkatan 2016 yang telah menempuh matakuliah tailoring, ditemukan bahwa penggunaan media pembelajaran pada matakuliah tailoring dengan materi pembuatan jas pria khususnya pada item menjahit kerah jas masih belum tersedia. Fakta lain yang ditemukan peneliti dilapangan yaitu dari 28 responden yang dipilih secara acak sebanyak 50\% mahasiswa berasal dari SMA dan 50\% berasal dari SMK sehingga tidak semua mahasiswa dapat menguasai teknik memasang dan menjahit kerah yang benar dengan mudah.

Pada kesempatan tersebut, peneliti ingin mengembangkan sebuah media pembelajaran menjahit kerah jas pria pada praktikum menjahit jas pria matakuliah tailoring yang berbasis mobile application, dimana mobile application itu sendiri adalah sebutan untuk aplikasi yang berjalan di mobile device (Purnama, 2010). Pembuatan media pembelajaran berbasis mobile application berdasar pada penggunaan gadget yang sudah menjalar disemua kalangan masyarakat tak terkecuali mahasiswa S1 Pendidikan Tata Busana dan sudah seperti kebutuhan utama, namun penggunaan gadget masih belum dimanfaatkan sebaik mungkin untuk belajar oleh mahasiswa. Berdasarkan observasi terhadap 28 mahasiswa S1 Pendidikan Tata Busana angkatan 2016 menunjukkan bahwa media sosial merupakan persentase terbesar dalam pemanfaatan smartphone oleh mahasiswa yaitu sebesar $67,8 \%$, sedangkan sebanyak 7,17\% responden memanfaatkan untuk game, 10,73\% untuk menonton film dan 14,4\% digunakan untuk belajar.

Media dikemas dalam bentuk gabungan beberapa media yaitu teks, video, suara dan gambar sebagai alat penyampai pesan yang dapat dioperasikan sendiri oleh pengguna. Media tersebut disimpan dengan format .apk dan dapat dijalankan pada platform android. Menurut Drawer dalam Marianda dkk (2014) menyatakan bahwa manusia dapat mengingat pesan yang disampaikan dan apabila dipraktikkan sekaligus dapat mencapai 80\%, sehingga menurut peneliti media berbasis mobile application ini dirasa sesuai untuk mahasiswa dalam menunjang kelancaran belajar. 


\section{Metode}

Pengembangan media pembelajaran berbasis mobile application pembuatan kerah jas pria ini menggunakan model pengembangan ADDIE yang dikembangkan oleh Dick and Carry (Mulyatiningsih, 2011). Berikut adalah bagan langkah-langkah model pengembangan ADDIE:

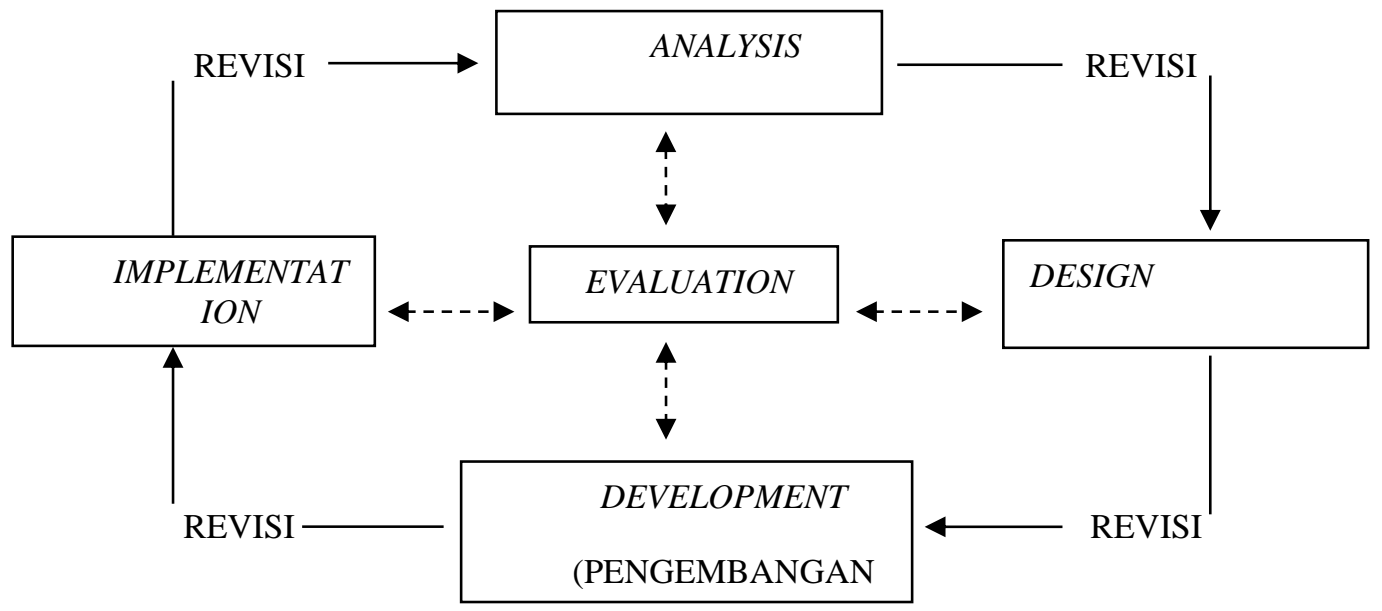

Gambar 1. Prosedur Pengembangan ADDIE oleh Mollenda \& Reiser

Uji coba dilakukan dengan cara mengumpulkan data menggunakan instrumen pengumpulan data berbentuk kuesioner dengan pengukuran skala Likert. Uji coba terbagi menjadi dua tahap yaitu uji validasi ahli dan uji coba kelompok kecil, dimana uji validasi dilakukan pada tiga ahli yaitu ahli materi, ahli media, dan ahli bahasa, sedangkan uji coba kelompok kecil dilakukan pada 30 mahasiswa S1 Pendidikan Tata Busana Universitas Negeri Malang yang pernah menempuh matakuliah tailoring. Jenis data yang diperoleh dari hasil pengumpulan data berupa data kuantitatif yang berbentuk angka dan data kualitatif yang berbentuk kritik, saran, tanggapan, maupun masukan. Setelah melakukan pengumpulan data, selanjutnya yaitu menganalisis atau mengolah data untuk mengetahui kevalidan dan kelayakan media yang dikembangkan yaitu dengan menghitung persentase jawaban yang diadaptasi dari Akbar (2015:83) dengan rumus:

Rumus mengolah data ahli materi, ahli media, dan ahli bahasa

$$
\mathrm{V}-\mathrm{ah}=\frac{\mathrm{TSe}}{\mathrm{TSh}} \times 100 \%
$$

Keterangan:

$\mathrm{V} \quad=$ Validasi

$\mathrm{V}$-ah = Validasi ahli

TSe = Total skor empirik yang dicapai (berdasarkan penilaian ahli, pengguna, atau nilai hasil uji kompetensi yang dicapai mahasiswa)

TSh = Total skor yang diharapkan

Rumus mengolah data audiens

$$
\text { Validitas audience }=\frac{\mathrm{TSe}}{\mathrm{TSh}} \times 100 \%
$$

Keterangan:

$\mathrm{TSe} \quad=$ Total skor empiric (nilai hasil uji kompetensi yang dicapai mahasiswa) 
TSh $=$ Total skor maksimal (hasil uji kompetensi maksimal yang diharapkan)

Data yang telah dianalisis menggunakan rumus diatas berbentuk persentase yang dapat digunakan sebagai pengambilan keputusan untuk menentukan kevalidan dan kelayakan dari media pembelajaran tersebut dengan mengacu pada kualifikasi penilaian.

\section{Hasil dan Pembahasan}

Hasil dari penelitian pengembangan ini adalah sebuah produk media pembelajaran berbasis mobile application pembuatan kerah jas pria bernama CollApp yang disimpan dengan format apk dan dapat dijalankan di platform android. Produk tersebut dapat digunakan dalam pembelajaran apabila telah dinyatakan valid dan layak oleh ahli media, ahli materi, ahli bahasa, dan responden.

Berdasarkan uji validasi yang dilakukan pada ahli materi, diperoleh hasil data dengan Total Skor Empiric (TSe) sejumlah 58 dari Total Skor Maksimal (TSh) sejumlah 64, jika dipersentasekan yaitu sebesar $90,6 \%$ dan dapat dikategorikan sangat valid, hal ini mengacu pada keriteria validasi dimana rentang persentase antara $85,01 \%$ - 100,00\% masuk dalam kriteria sangat valid. Selanjutnya sesuai dengan uji validasi kepada ahli media, diperoleh Total Skor Empirik (TSe) sebesar 76 dari Total Skor Maksimal (TSh) sebesar 80, maka didapatkan persentase sebesar 95\% yang tergolong dalam kriteria sangat valid. Hasil uji validasi selanjutnya yaitu kepada ahli bahasa, diperoleh Total Skor Empirik (TSe) sejumlah 70 dari Total Skor Maksimal (TSh) sejumlah 76, jika dipersentasekan yaitu sebesar 92,1\% yang termasuk dalam kategori sangat valid.

Setelah memperoleh data dari ketiga ahli dan telah dilakukan perbaikan atas kritik, saran maupun tanggapan yang didapat, dilakukan uji coba media kepada 30 responden, dari hasil tersebut, diperoleh Total Skor Empirik dengan jumlah 2338 dari Total Skor Maksimal dengan jumlah 2640 sehingga didapat persentase sebesar $88,58 \%$ yang termasuk dalam kategori sangat layak.

\section{Simpulan}

Produk mobile application pembuatan kerah jas pria dengan konten materi mulai dari desain, anatomi, alat dan bahan yang dibutuhkan, pola kerah jas, peletakan pola dan cutting, dan video menjahit kerah jas yang dikembangkan melalui model pengembangan ADDIE termasuk dalam jenis multimedia interaktif karena mengandung beberapa elemen didalamnya yaitu gambar, teks, video, suara, serta penggunaan media dapat dikontrol sendiri oleh pengguna. Dari hasil penelitian menunjukkan bahwa produk tersebut sudah sangat valid dari aspek materi, media, dan bahasa. Uji coba kelompok kecil yang dilakukan setelah uji validasi terhadap tiga ahli memperoleh hasil sangat layak dengan persentase $88,58 \%$, sehingga media ini dapat dinyatakan sangat layak untuk digunakan sebagai media pembelajaran dengan materi pembuatan kerah jas pria.

\section{Daftar Rujukan}

Akbar, S. 2015. Instrumen Perangkat Pembelajaran. Bandung: Remaja Rosda Karya

Marianda, G., Johar, A., \& Risdianto, E. (2014). Rancang bangun media pembelajaran berbasis multimedia interaktif konsep gaya pada mata pelajaran Fisika SMP kelas VIII. Rekursif: Jurnal Informatika, 2(2).

Mulyatiningsih, E. 2011. Metode Penelitian Terapan Bidang Pendidikan. Bandung: Alfabeta

Purnama, R. 2010. Mari Mengenal J2ME.2010. Jakarta: Prestasi Pustaka Publisher 
Jurnal Inovasi Teknik dan Edukasi Teknologi, 1(4), 2021, 283-287

Usman, U. 2013. Identifikasi Tingkat Kesulitan Pembuatan Blazer pada Mata Kuliah Tailoring. Skripsi tidak diterbitkan. Malang: FT UM 